\title{
Financial management efficiency of islamic boarding school based on information technology
}

\author{
Dedy Arisandi ${ }^{*}$, Romi Fadillah Rahmat ${ }^{1}$, Seniman $^{1}$, Sawaluddin $^{2}$ \\ ${ }^{1}$ Department of Information Technology, Universitas Sumatera Utara, Medan, Indonesia \\ ${ }^{2}$ Department of Mathematics, Universitas Sumatera Utara, Medan, Indonesia \\ *Email: dedyarisandi@usu.ac.id
}

\begin{abstract}
Utilization of information technology is a very important requirement for every component of society. Easy, fast and accurate data and information access can optimize routine daily work. Mawaridussalam Islamic boarding school Batang Kuis as an Islamic education institution that plays a role in shaping the character and personality of the next generation of the nation is expected to be able to optimally manage finances and provide good service to the academics of the Islamic boarding school. Until now, financial management is still done manually using bookkeeping, there is no specific financial application used in Islamic boarding school financial management, so it is difficult and slow in recording, processing, controlling and reporting financial activities. Based on these problems, an application is needed that can be used by the treasurer and board of boarding school leaders for financial management systematically. The method applied is the User Centered Design approach and the target that was successfully achieved is the availability of web-based financial management applications that are used properly to increase the efficiency and effectiveness of financial management in Islamic boarding schools.
\end{abstract}

\section{Keyword: Financial Applications, Islamic Boarding Schools, User Centered Design}

\begin{abstract}
Abstrak
Pemanfaatan Teknologi informasi merupakan kebutuhan yang sangat penting pada setiap komponen masyarakat. Akses data dan informasi yang mudah, cepat dan akurat dapat mengoptimalkan pekerjaan yang rutin dilakukan seharihari. Pondok Pesantren Mawaridussalam Batang Kuis sebagai lembaga pendidikan Islam yang berperan membentuk karekter dan kepribadian generasi penerus bangsa diharapkan mampu secara optimal malakukan pengelolaan keuangan dan memberikan pelayanan yang baik kepada sivitas akademika Pondok Pesantren. Sampai saat ini pengelolaan keuangan masih dilakukan secara manual menggunakan pembukuan, belum ada aplikasi keuangan khusus yang digunakan dalam pengelolaan keuangan Pondok Pesantren sehingga sulit dan lambat dalam aktivitas pencatatan, pemrosesan, pengontrolan dan pelaporan keuangan. Oleh karena itu dibutuhkan suatu aplikasi yang dapat dimanfaatkan oleh Bendahara dan Pimpinan Pondok Pesantren untuk pengelolaan keuangan secara sistematis. Metode yang diterapkan adalah dengan pendekatan User Centered Design dan target yang berhasil dicapai adalah tersedianya aplikasi untuk pengelolaan keuangan berbasis web yang digunakan dengan baik untuk meningkatkan efisiensi dan efektivitas pengelolaan keuangan di Pondok Pesantren.
\end{abstract}

Kata Kunci: Aplikasi Keuangan, Pondok Pesantren, User Centered Design

\section{PENDAHULUAN}

Pondok pesantren adalah sebuah lembaga pendidikan dan pengajaran agama, umumnya dengan cara non klasikal, seorang kiai mengajarkan ilmu agama Islam kepada santri-santri berdasarkan kitab-kitab yang ditulis dalam bahasa Arab oleh ulama abad pertengahan, dan biasanya para santri tinggal di pondok (asrama) pesantren tersebut (Prasodjo et al., 2001). Pondok pesantren sebagai lembaga pendidikan islam harus tetap terjaga eksistensinya yaitu harus mampu menjawab tantangan global sehingga keberadaannya tidak terkikis dan ketinggalan dalam segala aktivitas. 
Untuk mewujudkan pendidikan yang berkualitas, perlu adanya pengelolaan secara menyeluruh dan profesional terhadap sumber daya yang ada dalam lembaga pendidikan islam. Salah satu sumber daya yang perlu dikelola dengan baik dalam lembaga pendidikan adalah masalah keuangan. Dalam konteks ini, keuangan merupakan sumber daya yang sangat diperlukan sekolah islam sebagai alat untuk melengkapkan berbagai sarana dan prasarana pembelajaran di sekolah islam, meningkatkan kesejahteraan guru, layanan, dan pelaksanaan program supervisi (Arifin, 2016).

Pondok Pesantren Mawaridussalam didirikan pada tahun 2010 yang beralamat di Jl. Peringgan Dusun III Desa Tumpatan Nibung, Batang Kuis, Kabupaten Deli Serdang, Propinsi Sumatera Utara. Pondok Pesantren merupakan lembaga pendidikan yang didambakan dapat membentuk watak, kepribadian dan peradaban bangsa serta mencerdaskan kehidupan bangsa yang berbasis pada keimanan dan ketakwaan kepada Allah SWT serta akhlak mulia.

Pondok pesantren yang memiliki jumlah santri yang banyak, memiliki banyak unit usaha, dan cita-cita yang mulia dapat berjalan dan terkontrol dengan baik jika didukung dengan pemanfatan teknologi informasi yang baik pula. Sampai dengan saat ini di Ponpes Mawaridussalam ada beberapa bidang yang belum menerapkan penggunaan teknologi informasi diantaranya pengelolaan keuangan Ponpes. Pencatatan data santri, pencatatan pembayaran uang SPP, pembayaran uang tahunan, pencatatan pengeluaran untuk pengambilan uang anggaran tiap bagian, dan pencatatan-pencatatan lainnya masih dilakukan secara manual menggunakan pembukuan. Pembuatan rekapitulasi pembayaran SPP dan Tunggakan SPP Santri dilakukan dengan mensortir secara manual dari buku. Begitu pula dalam penyajian laporan keuangan harian, bulan, tahunan, kas, pengeluaran, dan laba rugi masih lambat dan sulit dilakukan karena harus melakukan rekapitulasi dan menulis hasil rekapitulasi tersebut menggunakan aplikasi Worksheet Microsoft Excel dan Belum optimalnya pemanfaatan teknologi informasi dalam bentuk poenggunaan software aplikasi yang diterapkan secara khusus sebagai media untuk pengelolaan keuangan Ponpes agar dapat diterapkan secara efektif dan efisien.

Berdasarkan permasalahan tersebut, pihak Bendahara Ponpes meminta tim pengusul pengabdian untuk mengembangkan aplikasi keuangan khusus berbasis web dengan pendekatan user centered desain yang dapat dijalankan pada jaringan lokal Ponpes dan dapat secara sistematis mampu digunakan untuk mengelola kuangan Ponpes dengan cepat, akurat, efektif dan efisien.

\section{METODE PENGABDIAN}

Metode pendekatan yang di tawarkan adalah dengan pendekatan User Centered Design (UCD). Konsep dari UCD adalah user sebagai pusat dari proses pengembangan sistem, dan tujuan/sifat-sifat, konteks dan lingkungan sistem semua didasarkan dari pengalaman pengguna (Amborowati, 2012). Pendekatan ini dilakukan untuk memfasilitasi pengguna sistem untuk dapat menerapkan apa yang mereka inginkan. Aktivitas yang dilakukan meliputi analisis kebutuhan aplikasi, pengembangan aplikasi, pemberian pelatihan kepada seluruh elemen desa yang terlibat dalam proses penyaluran aspirasi masyarakat.

Pada pelaksanaan pengabdian kepada masyarakat ini, terdapat tahapan-tahapan aktivitas yang dilakukan untuk pengembangan aplikasi keuangan pondok pesantren mawaridussalam sebagaimana yang disajikan pada gambar 2.1. 


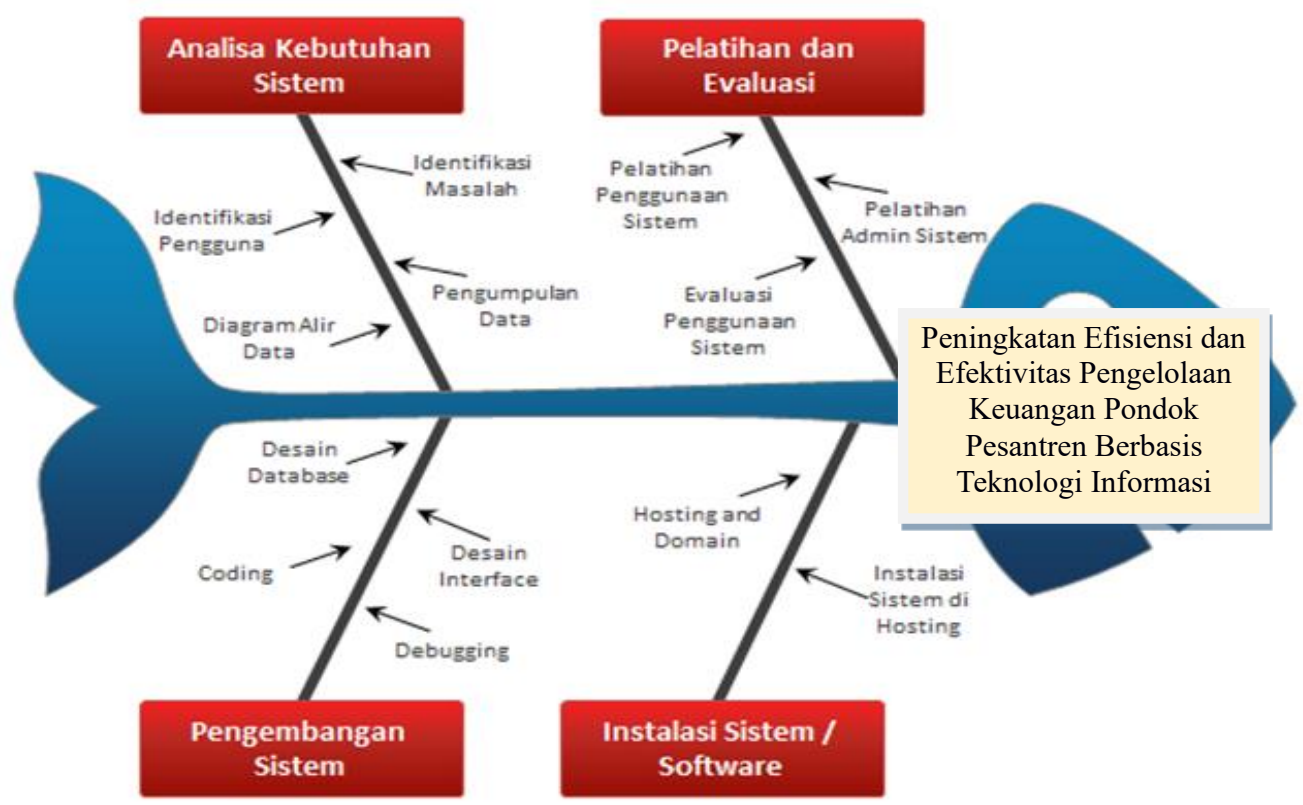

Gambar 2.1. Diagram Fishbone Tahapan Pengabdian kepada Masyarakat

Berdasarkan Gambar 2.1 di atas, pengabdian kepada masyarakat yang dilakukan terdiri atas 4 (empat) tahapan kerja. Tahapan kerja yang dimaksud adalah sebagai berikut:

\subsection{Analisis Kebutuhan Aplikasi}

Analisis kebutuhan aplikasi ini merupakan tahap awal yang dilaksanakan oleh tim pengabdian kepada masyarakat. Tim akan mengumpulkan analisis kebutuhan untuk pengembangan sistem dengan cara mengidentifikasi permasalahan pengguna yang nantinya akan mendukung pengembangan aplikasi. Pada tahap ini, tim pengabdian juga mengumpulkan data yang berguna untuk mengembangkan modul-modul yang nantinya akan diimplementasikan ke dalam aplikasi.

Untuk membantu menganalisis sistem yang dikembangkan, tim pengabdian kepada masyarakat membuat use case diagram aplikasi keuangan pondok pesantraen Mawaridussalam yang dapat dilihat pada gambar 2.2.

\subsection{Pengembangan Aplikasi}

Tahap kerja selanjutnya setelah analisa kebutuhan aplikasi adalah pengembangan aplikasi. Pengembangan aplikasi merupakan tahap kerja kedua dalam pengabdian kepada masyarakat dimana tim pengabdian melakukan pengembangan sistem aplikasi yang memiliki fitur-fitur sesuai dengan solusi dari permasalahan yang telah dikumpulkan melalui analisis kebutuhan aplikasi. Dengan berdasarkan pada hasil analisis, tim pengabdian merancang desain basis data dan desain tampilan yang digunakan pada implementasi aplikasi. Setelah desain basis data dan tampilan diselesaikan, tim pengabdian melanjutkan pengembangan sistem ke dalam tahap coding. Setelah melakukan peng-coding-an, tim melakukan proses terakhir pada tahap kerja kedua ini yakni debugging. Debugging adalah menemukan dan menghilangkan ketidaksempurnaan program ini (Al Fatta, 2007). Debugging bertujuan untuk menemukan celah dan kesalahan serta memperbaiki kesalahan-kesalahan yang timbul secara sengaja ataupun tanpa sengaja. 


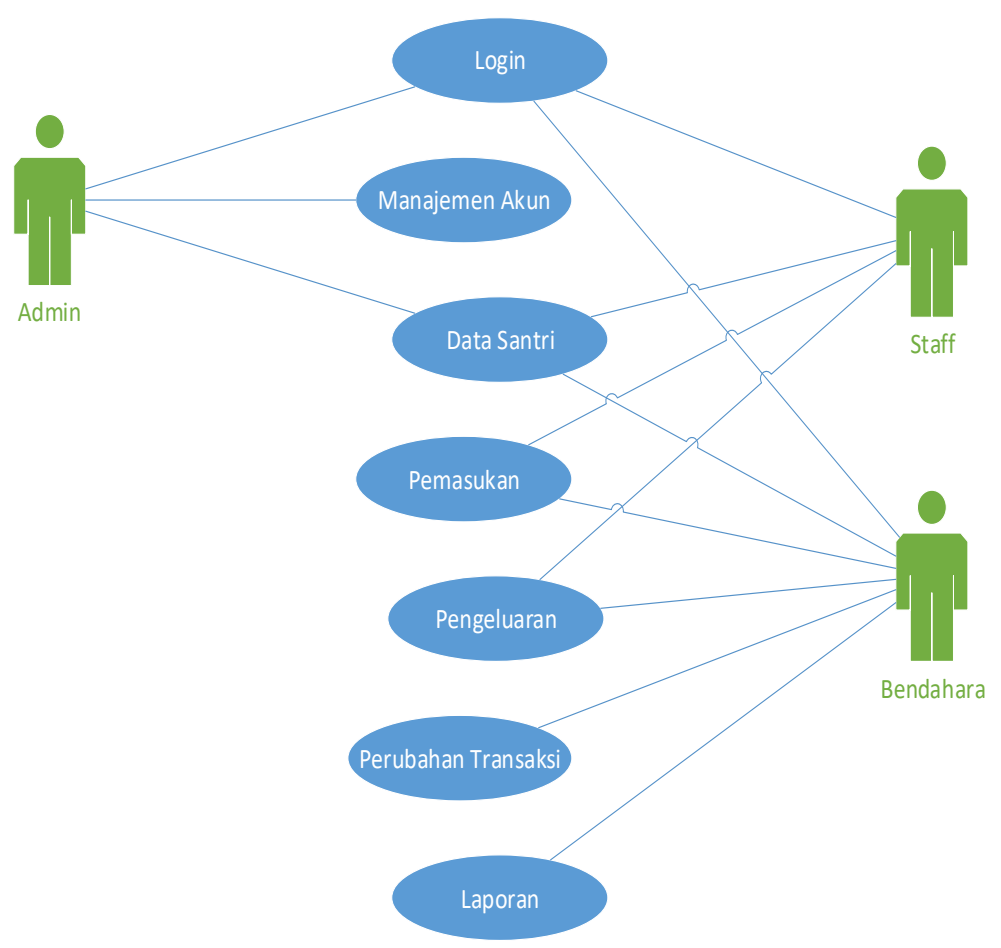

Gambar 2.2. Use Case Diagram Aplikasi Keuangan Ponpes

\subsection{Instalasi Aplikasi}

Tahap ini melakukan instalasi aplikasi keuangan untuk Ponpes Mawaridussalam. Selain itu, tim pengabdian juga akan memberikan infrastruktur perangkat yang akan menunjang penggunaan sistem yang telah dioptimalkan. Selanjutnya, aplikasi yang telah selesai dikembangkan, akan diinstal di server dan komputer yang terdapat di Ponpes. Aplikasi yang dibangun memiliki klasifikasi hak akses yang berbeda-beda untuk setiap akun. Misalnya untuk operator keuangan hanya dapat memasukkan data pembayaran dan pengeluaran saja, berbeda dengan bendahara atau admin.

\subsection{Pelatihan dan Evaluasi}

Tahap kerja akhir dari kegiatan pengabdian kepada masyarakat adalah Pelatihan dan Evaluasi. Pada tahap ini, tim mengadakan pelatihan kepada operator keuangan, bendahara, dan admin aplikasi. Pada tahap ini dilakukan evaluasi sistem dan dilihat kinerja sistem apakah mudah dimengerti dan dapat digunakan serta dipahami dengan baik penggunaannya. Evaluasi juga dilakukan terkait dengan kinerja sistem berupa kecepatan, keamanan, integritas dan kredibilitas data untuk kenyamanan dalam mengakses sistem. 


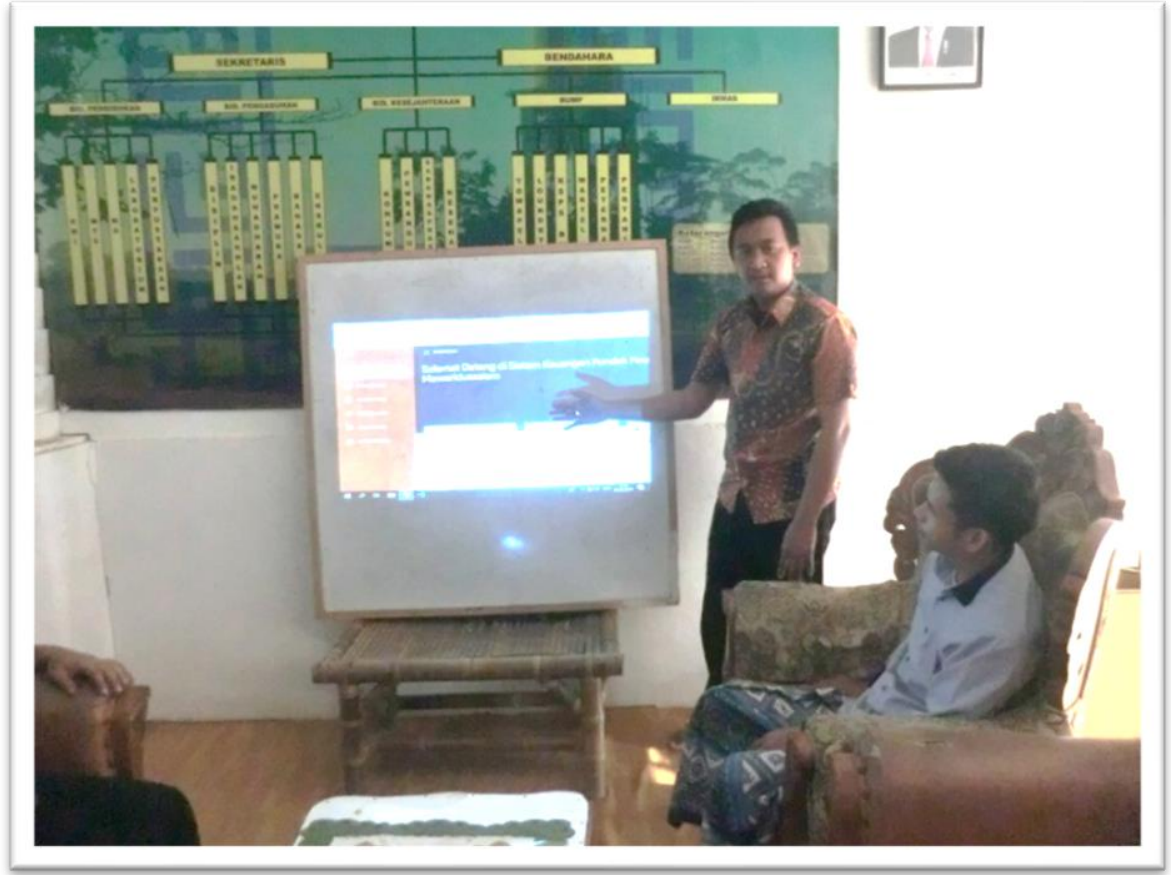

Gambar 2.3. Pelatihan Aplikasi Keuangan Ponpes Mawaridussalam

\section{HASIL DAN PEMBAHASAN}

Hasil yang diperoleh dalam penerapan pengembangan aplikasi keuangan berbasis web yang dilaksanakan di Ponpes Mawaridussalam menunjukkan peningkatan efisiensi dan efektifitas pengelolaan keuangan yang terlihat dari mudahnya pencatatan data pembayaran uang bulanan SPP, pembayaran uang tahunan, pencatatan pengeluaran, pembuatan rekapitasi, melihat histrori pembayaran santri, pembuatan laporan bulanan dan tahunan menjadi sangat mudah dan sistematis.

Tampilan beranda untuk Admin berisi menu-menu perintah seperti manajemen user, siswa, kelas, dan import data siswa.

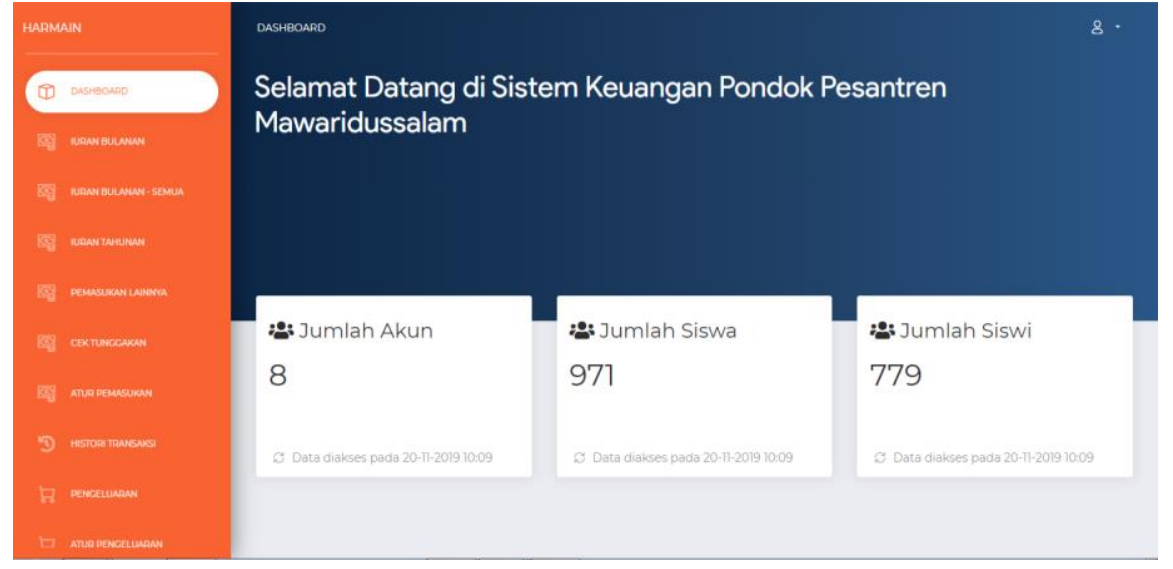

Gambar 3.1. Tampilan Beranda Aplikasi Keuangan Ponpes Mawaridussalam 
Pada tampilan beranda aplikasi keuangan terdapat banyak menu yang dapat dipilih dan digunakan oleh pengguna diantaranya dasboard, iuran bulanan, iuran tahunan, pemasukan lainnya, cek tunggakan, atur pemasukan, histori transaksi, pengeluaran, dan aturan pengeluaran. Pada tampilan dasbor ditampilkan jumlah akun pengguna, jumlah siswa, dan jumlah siswi di Ponpes Mawaridussalam.

Pada menu akun pengguna pihak ponpes dapat melakukan pembuatan dan pengaturan pengguna aplikasi keuangan. Menu ini menampilkan user yang terdaftar pada aplikasi, tingkatan pengguna dibagai menjadi 3 tingkatan yaitu admin, bendahara, dan staff keuangan. Untuk mencatat pembayaran iuran santri, pengguna dapat mengakses menu pembayaran iuran, menu ini menampilkan form pembayaran iuran bulan dan tahunan seperti yang ditunjukkan pada gambar 3.2.

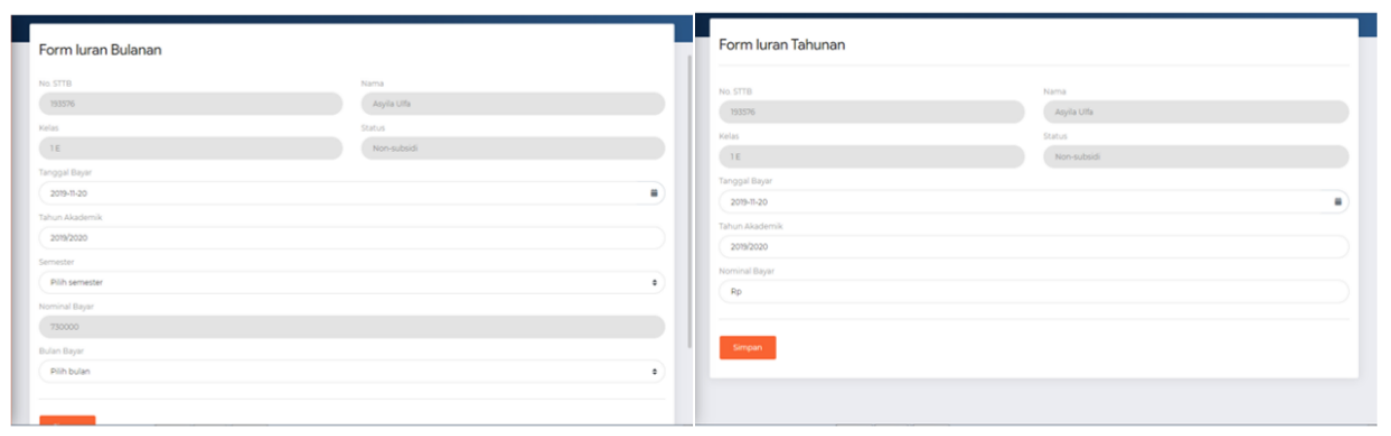

Gambar 3.2. Form Pembayaran Iuran Bulanan dan Tahunan

Menu berikutnya adalah menu untuk memasukkan penerimaan/pemasukan selain dari pemasukan SPP ataupun iuran tahunan dari siswa. Informasi yang diperlukan yaitu tanggal bayar, keterangan, nominal, dan kode transaksi. Tampilan berikutnya menu untuk menampilkan histori transaksi yang pernah dilakukan pada aplikasi keuangan ini mulai dari pengeluaran hingga pemasukan. Informasi yang ditampilkan mulai dari kode transaksi hingga petugas yang melakukan pencatatan pada setiap transaksi yang dilakukan.

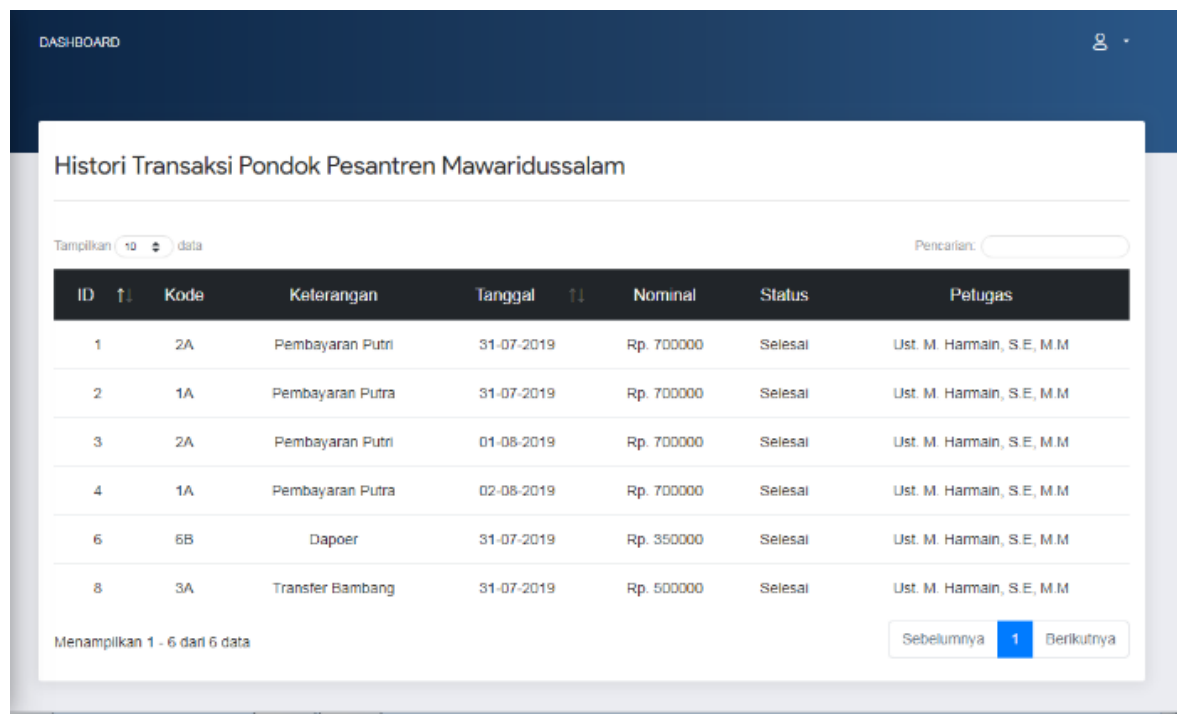

Gambar 3.3. Form Histori Transaksi

Hasil akhir yang diperoleh dari aplikasi ini adalah untuk mencetak laporan rekapitulasi keuangan. Ada beberapa kategori yaitu laporan penerimaan SPP, laporan keuangan, laporan pengeluaran, laporan 
keuangan harian (laporan detail), dan juga laporan per kategori. Laporan dicetak dengan memilih bulan dan tahun yang diinginkan untuk dicetak rekapitulasinya.
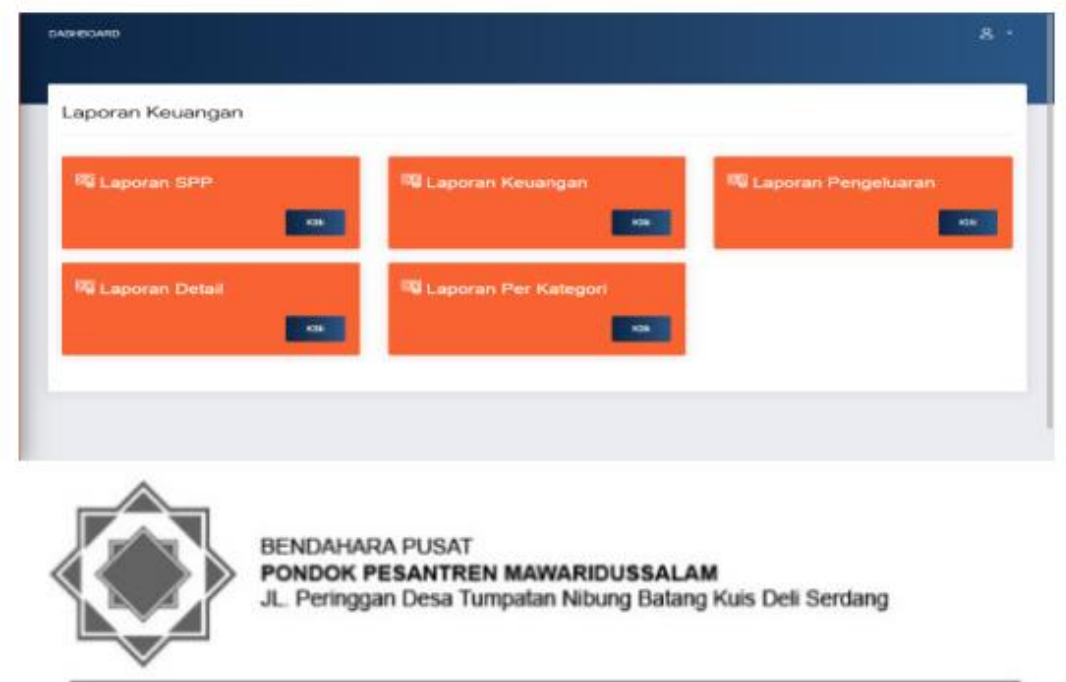

BENDAHARA PUSAT

PONDOK PESANTREN MAWARIDUSSALAM

Jl. Peringgan Desa Tumpatan Nibung Batang Kuis Deli Serdang

\begin{tabular}{|c|c|c|c|c|c|}
\hline \multicolumn{6}{|c|}{$\begin{array}{l}\text { LAPORAN KEUANGAN } \\
\text { BULAN JUU } 2019\end{array}$} \\
\hline NO. & TANGGML. & HARI & DEBET & KREDIT & SALDO \\
\hline & & & & & $\mathrm{Re}$ \\
\hline 1 & $01 / 07 / 2019$ & SENIN & $\mathrm{RpO}$ & $\operatorname{Rp} 570.000$ & $-\operatorname{Rp} 570.000$ \\
\hline 2 & $07 / 07 / 2019$ & MINGGU & Rp 700.000 & $\mathrm{RpO}$ & Rp130.000 \\
\hline 3 & $08 / 07 / 2019$ & SENIN & Rp 700.000 & $\mathrm{RpO}$ & Rp830.000 \\
\hline 4 & $09 / 07 / 2019$ & SELASA & Rp 700.000 & $\mathrm{RpO}$ & $R p 1.530 .000$ \\
\hline 5 & $10 / 07 / 2019$ & RABU & Rp 700.000 & $\mathrm{RpO}$ & $R p 2.230 .000$ \\
\hline 6 & $11 / 07 / 2019$ & KAMIS & $8 p 700.000$ & $\mathrm{Rp0}$ & $R p 2.930 .000$ \\
\hline 7 & $12 / 07 / 2019$ & IUMAT & Rp 700.000 & $\mathrm{RpO}$ & $R p 3.630 .000$ \\
\hline 8 & $13 / 07 / 2019$ & SABTU & Rp 700.000 & $\mathrm{RpO}$ & $R p 4.330 .000$ \\
\hline 9 & $14 / 07 / 2019$ & MINGGU & Rp700.000 & $\mathrm{RpO}$ & $R p 5.030 .000$ \\
\hline 10 & $17 / 07 / 2019$ & RABU & Rp700.000 & $\mathrm{RpO}$ & $R p 5.730 .000$ \\
\hline 11 & $18 / 07 / 2019$ & KAMIS & Rpp700.000 & $\mathrm{RpO}$ & Rp 6.430 .000 \\
\hline 12 & $19 / 07 / 2019$ & IUMAT & Rp1.400.000 & $\mathrm{RpO}$ & $R p 7.830 .000$ \\
\hline 13 & $21 / 07 / 2019$ & MINGGU & Rp700000 & $\mathrm{RpO}$ & Rp8.530.000 \\
\hline 14 & $22 / 07 / 2019$ & SENIN & Ap 700.000 & $8 \mathrm{RpO}$ & $R p 9.230 .000$ \\
\hline 15 & $31 / 07 / 2019$ & RABU & $R p 1.900 .000$ & $R p 350.000$ & Rp 10.780 .000 \\
\hline 16 & LAIN-LAN & & Rp500.000 & & Ap11.280.000 \\
\hline \multicolumn{3}{|c|}{ TOTAL KESELURUHAN } & $\operatorname{Rp} 12.200 .000$ & Rp920.000 & Rp11.280.000 \\
\hline
\end{tabular}

Gambar 3.4. Form Laporan Keuangan

\section{KESIMPULAN}

Adapun kesimpulan yang dapat ditarik dari pengabdian masyarakat ini adalah:

1. Pengembangan aplikasi untuk pengelolaan keuangan ini terbukti dapat diterapkan dengan baik sebagai strategi pengingkatan efisiensi dan efektivitas pengelolaan keuangan mitra.

2. Dengan pengembangan aplikasi keuangan ini staf keuangan, bendahara, dan pimpinan Ponpes dapat bersama-sama meningkatkan kemajuan Pondok Pesantrennya dengan pemanfaatan teknologi informasi.

3. Bendahara pondok pesantren memiliki pusat data yang setiap saat dapat digunakan oleh pihak-pihak terkait dalam pengambilan kebijakan dimasa mendatang. 
Dedy, et al Financial management efficiency of islamic boarding school based on information technology

\section{UCAPAN TERIMAKASIH}

Kegiatan Pengabdian Kepada Masyarakat ini dapat teraksana berkat bantuan dana NON PNBP Universitas Sumatera Utara sesuai Kontrak Pelaksanaan Program Pengabdian Kepada Masyarakat Program Mono Tahun Reguler Tahun Anggaran 2019 dengan nomor kontrak 327/UN5.2.3.2.1/PPM/2019, Tanggal 20 Mei 2019.

\section{DAFTAR PUSTAKA}

Al Fatta, Hanif. (2007). Analisis dan Perancangan Sistem Informasi untuk Keunggulan Bersaing Perusahaan dan Organisasi Modern. Andi. Yogyakarta.

Amborowati, A. (2012). Rancangan Sistem Pameran Online menggunakan Metode UCD (User Centered Design). STMIK AMIKOM.

Arifin, Miftahol. (2016). Manajemen Keuangan Pondok Pesantren, Jurnal Pendidikan dan Manajemen Islam. Fikrotuna. Pamekasan.

Jogiyanto. (2005). Analisis \& Desain Sistem Informasi: pendekatan terstruktur teori dan praktek aplikasi bisnis. Andi, Yogyakarta.

Prasodjo, Sudjoko et al. (2001). "Profil Pondok Pesantren," dalam Abuddin Nata(ed), Sejarah Pertumbuhan dan Perkembangan Lembaga-Lembaga Pendidikan Islam di Indonesia. Grasindo. Jakarta. 